\title{
TEMPORAL TRENDS OF PERFLUOROALKYL SUBSTANCES (PFAS) IN EGGS OF COASTAL AND OFFSHORE BIRDS: INCREASING PFAS LEVELS ASSOCIATED WITH OFFSHORE BIRD SPECIES BREEDING ON THE PACIFIC COAST OF CANADA AND WINTERING NEAR ASIA
}

\author{
Aroha Miller, $\dagger$ John E. Elliott, ${ }^{*} \dagger \ddagger$ Kyle H. Elliott, $§$ Sandi Lee, $\ddagger$ and Francois Cyr\| \\ $\dagger$ Department of Applied Biology, University of British Columbia, Vancouver, British Columbia, Canada \\ $\ddagger$ Science and Technology Branch, Pacific Wildlife Research Centre, Environment Canada, Delta, British Columbia, Canada \\ $\S$ Department of Natural Resource Sciences, McGill University, Sainte-Anne-de-Bellevue, Quebec, Canada \\ ||Environment Canada, National Wildlife Research Centre, Ottawa, Ontario, Canada
}

(Submitted 29 December 2014; Returned for Revision 31 December 2014; Accepted 11 March 2015)

\begin{abstract}
Perfluoroalkyl substances (PFAS) such as perfluoroalkyl carboxylates (PFCAs) and perfluoroalkyl sulfonates (PFSAs) have become virtually ubiquitous throughout the environment, and, based on laboratory studies, have known toxicological consequences. Various national and international voluntary phase-outs and restrictions on these compounds have been implemented over the last 10 to 15 years. In the present study, we examine trends (1990/1991-2010/2011) in aquatic birds (ancient murrelet, Synthliboramphus antiquus [2009 only]; Leach's storm-petrels, Oceanodroma leucorhoa; rhinoceros auklets, Cerorhinca monocerata; double-crested cormorants, Phalacrocorax auritus; and great blue herons, Ardea herodias). The PFCA, PFSA, and stable isotope $\left(\delta^{15} \mathrm{~N}\right.$ and $\left.\delta^{13} \mathrm{C}\right)$ data collected from these species from the Pacific coast of Canada, ranging over 20 to 30 years, were used to investigate temporal changes in PFAS coupled to dietary changes. Perfluorooctane sulfonic acid (PFOS), the dominant PFSA compound in all 4 species, increased and subsequently decreased in auklet and cormorant eggs in line with the manufacturing phase-out of PFOS and perfluorooctanoic acid (PFOA), but concentrations continuously increased in petrel eggs and remained largely unchanged in heron eggs. Dominant PFCA compounds varied between the offshore and coastal species, with increases seen in the offshore species and little or variable changes seen in the coastal species. Little temporal change was seen in stable isotope values, indicating that diet alone is not driving observed PFAS concentrations. Environ Toxicol Chem 2015;34:1799-1808. (C) 2015 SETAC
\end{abstract}

Keywords: Perfluoroalkyl carboxylic acids Perfluoroalkyl sulfonic acids Seabirds

\section{INTRODUCTION}

Perfluoroalkyl substances (PFAS) such as sulfonates (PFSAs) and carboxylates (PFCAs) are anthropogenic pollutants used in various industrial and consumer products. Such products include water and stain proofing agents, grease- and oil-resistant packaging for food products, nonstick cookware [1], surfactants, agrochemicals [2], and fire-fighting foams [3], among other uses [4]. Some PFAS are still considered emerging contaminants despite their production since the 1950s [4]. Bioaccumulation potential of PFCAs increases with increasing chain length, with compounds comprising more than 7 fluorinated carbons considered bioaccumulative [5]. The PFSAs, especially longer-chain compounds, are bioaccumulative and biomagnify in the food web [6]. These chemicals are partly hydrophilic and partly lipophilic because of the presence of a carboxylate or sulfonate functional group on the carbon chains [5] and tend to accumulate in protein-rich tissues such as blood and liver [5]. Because of the strength of the carbonfluorine bond [7], these chemicals are highly resistant to degradation [8], making PFAS a persistent environmental contaminant.

Atmospheric and oceanic water transport can contribute to the long-range dispersal of PFAS [4,9]. Those two routes are likely transport mechanisms for PFAS to remote regions such as the Arctic [10]. Air samples from northwestern Europe indicate

All Supplemental Data may be found in the online version of this article.

* Address correspondence to John.Elliott@ec.gc.ca.

Published online 18 May 2015 in Wiley Online Library

(wileyonlinelibrary.com).

DOI: $10.1002 /$ etc. 2992 that PFSAs may be directly transported atmospherically on particulates [11], whereas atmospheric deposition has been suggested as a major contributor of PFAS in some regions (e.g., the Baltic Sea) [12]. In part because of that potential for longrange transport, PFAS have been found globally in the terrestrial, marine, and freshwater environments and are now virtually ubiquitous in matrices from those locations, being found in birds [13-16], aquatic organisms [17-19], and mammals [20-23], including humans [19,24]. The deep ocean has been identified as an environmental sink for these chemicals $[4,9]$, possibly via the sedimentation of sinking particles [10]. Thus, a need exists for ongoing monitoring of PFAS across a range of environments. Aquatic birds are ideally situated, in terms of both trophic levels and geographical location, to sample the marine, estuarine, and freshwater environments, and they are among the most widely used indicator species for surveillance work [25].

The long-range transport potential and properties of PFAS have caused concern about possible environmental and toxicological effects, especially neurobehavioral consequences, in animals exposed during early development (reviewed in Houde et al. [10]), and altered inflammatory, adaptive, and immune responses in various animal models (reviewed in Elliott and Elliott [25]). As such, voluntary and regulatory restrictions on use, production, and manufacture of various PFAS have been, and are still being, implemented. In 2000, 3M, the major global producer of PFAS, phased out production of perfluorooctane sulfonic acid (PFOS), perfluorooctanoic acid (PFOA), and related products [26]. Multiple jurisdictions have restricted PFOS and PFOA throughout the 2000s, including the US Environmental Protection Agency (USEPA) [27], Canadian 
environmental and health authorities [28], and the European Union [29]. In addition, PFOS has been included as 1 of the 9 new persistent organic pollutants (POPs) under the Stockholm Convention on POPs since 2009.

Despite those measures, PFAS continue to be detected in the environment [14,20,21,30-32]. Diet is a key exposure route [19,33]; thus, examination of dietary changes using $\mathrm{N}$ and $\mathrm{C}$ stable isotopes $\left(\delta^{15} \mathrm{~N}\right.$ and $\left.\delta^{13} \mathrm{C}\right)$ as proxies for trophic position and spatial patterns can help elucidate dietary effects on contaminant concentrations [34]. Bird eggs are widely used for environmental contaminant monitoring, and trophic position can be examined in these same matrices by stable isotope analysis $[35,36]$ to account for variation in contaminant concentrations resulting from dietary changes rather than variation in environmental abundance of contaminants [37].

In light of the national and international phase-outs and restrictions implemented for PFAS over the last 10 to 15 years, and their potential to cause environmental and toxicological harm, in the present study we used long-term data collections to: 1) investigate temporal changes in 13 PFAS in 2 oceanic seabird species (rhinoceros auklets, Cerorhinca monocerata, 19902010; Leach's storm-petrels, Oceanodroma leucorhoa, 1990/ 1991-2011); and in 2 coastal bird species (double-crested cormorants, Phalacrocorax auritus, 1973-2011; great blue herons, Ardea herodias, 1982-2012); 2) investigate whether the phase-out of PFOS and PFOA in 2000 has had a noticeable effect on the concentrations of these compounds in these species; and 3) determine whether any relationship exists between PFAS and diet in these populations. In addition, differences between these 4 species and ancient murrelets (Synthliboramphus antiquus) were investigated for the most recent year of sampling available, because data for this species were available for 2009 .

\section{METHODS}

\section{Study species}

The ancient murrelet (hereafter murrelet) is an offshore, subsurface feeder that preys on zooplankton and small, schooling fish [38]. Adults feed almost exclusively offshore when not on land breeding [38]. Leach's storm-petrel (hereafter petrel) is found throughout the northern Atlantic and Pacific Oceans [39]. It is a planktivorous surface feeder that may feed many hundreds of kilometers beyond the continental shelf edge outside of the breeding season [39]. The rhinoceros auklet (hereafter auklet) is an epipelagic piscivorous feeder [40] inhabiting temperate waters of the northern Pacific [41]. Auklets migrate south in winter [42]. These species return to land to lay a single (auklets, petrels) or 2 eggs (murrelets) annually in a colonial burrow-nesting environment $[43,44]$. Thus, during the breeding season, including the prelaying period when nutrients are deposited into the egg, auklets feed close $(<50 \mathrm{~km})$ to the North American coast, whereas petrels feed up to hundreds of kilometers beyond the North American coast. Little is known about activity during the nonbreeding season, but band recoveries in auklets demonstrate that at least some remain close to the North American coast, whereas petrels roam across most of the North Pacific $[45,46]$. Double-crested cormorants (hereafter cormorant) and great blue herons (hereafter heron) are both widely distributed across North America [47]. Cormorants are found from resident coastal near-shore species in our Salish Sea study area, western Pacific coast of Canada [47], and herons are year-round residents in freshwater and marine habitats within this region and are a widely used indicator species $[48,49]$.
Sites, sampling matrix, and design

All eggs were sampled from the Pacific coast of British Columbia, Canada. Murrelet eggs were sampled from Langara Island, and auklet and petrel eggs were sampled from 3 islands-Cleland Island (auklet, petrel), Lucy Island (auklet), and Hippa Island (petrel; Figure 1). All of these islands are distant from large urban centers and located in open coastal positions; thus, direct anthropogenic input is minimal. Auklet and petrel eggs were collected every 4 years during spring and early summer (late April to early July); murrelet eggs were collected in May 2009. Not all sites were sampled in the same years because of cost and logistics (Table 1). Cormorant eggs have been collected from Mandarte Island since 1979, an uninhabited island approximately $60 \mathrm{~km}$ southwest of Vancouver (Figure 1). Birds from this colony forage in the South Salish Sea [50]. Heron eggs have been collected from a colony formerly on the grounds of the University of British Columbia and now located in Stanley Park, an urban park of approximately 400 ha located in downtown Vancouver. Herons at both the University of British Columbia and Stanley Park forage in the Fraser River estuary and Burrard Inlet and are therefore referred to throughout as the Fraser River colony. Details on sampling matrix and design have been presented previously [51,52].

Briefly, 15 fresh eggs were collected from individual nests every 4 years for auklets and petrels and stored frozen until prepared for analysis. To conserve archived samples, eggs were analyzed retrospectively as 1 pool of 15 eggs from 1990 to 1991 until either 2002 to 2003 or 2006 to 2007. Eggs were subsequently analyzed as 5 pools of 3 eggs each, as well as being reanalyzed as 1 group of 15 , as per previous years. Total number of eggs collected for herons and cormorants has varied over the years, as has year of sampling (Table 1). For each egg, the entire contents were homogenized. Approximately $1 \mathrm{~g}$ homogenized content from each egg pool was subsampled and sent for chemical analysis. Subsamples were archived individually and as equal weight pools at $-40{ }^{\circ} \mathrm{C}$ at the Canadian Wildlife Service National Wildlife Specimen Bank [53]. Moisture and lipid content were recorded for pooled samples.

\section{Chemical analysis}

Samples were analyzed at the National Wildlife Research Centre, Ontario, Canada. Egg contents were homogenized and stored at $-20{ }^{\circ} \mathrm{C}$ before extraction. The PFAS extraction, cleanup, and analysis for the egg homogenates has been described [13]. Briefly, aliquots of $0.5 \mathrm{~g}$ to $1 \mathrm{~g}$ wet weight were spiked with labeled internal standards (Supplemental Data, Table S1), and subsequently extracted, cleaned, and fractionated using weak anion exchange solid-phase extraction cartridges. Separation of the target compounds was carried out on Waters model 2695 high-performance liquid chromatography equipped with an ACE 3 C18 analytical column $(50 \mathrm{~mm} \times 2.1 \mathrm{~mm} \mathrm{D}$, 3- $\mu \mathrm{m}$ particle size; Advanced Chromatography Technologies) coupled to a Waters Quattro Ultima triple quadrupole mass spectrometer (Waters). An electrospray ionization source in negative mode was used for analysis of PFCAs and PFSAs. Quantification was performed by using an internal standard approach.

\section{Quality control}

A known amount of labeled compound (surrogate) was added to every sample before extraction because the native and labeled analogs exhibit similar effects on extractions, 


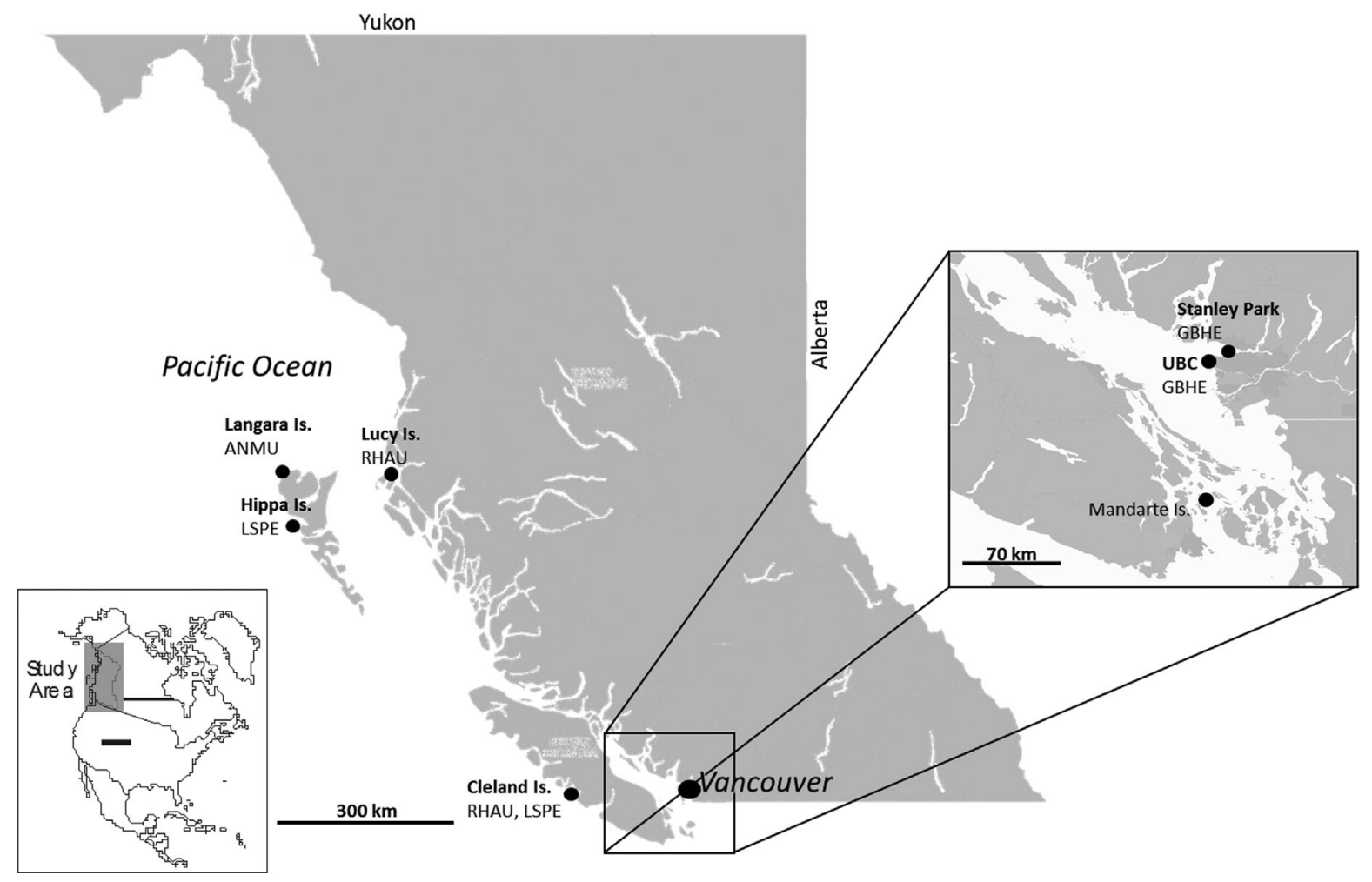

Figure 1. Map of the Pacific coast of British Columbia, Canada, indicating the approximate location of each sampled seabird colony. Inset, bottom left: Gray area indicates the Pacific coast of Canada in relation to the North American continent. Inset, right: Sampled colonies of great blue heron (GBHE; Ardea herodias) and double-crested cormorant (Phalacrocorax auritus). RHAU = rhinoceros auklet (Cerorhinca monocerata); LSPE $=$ Leach's storm petrel (Oceanodroma leucorhoa); and ANMU = ancient murrelet (Synthliboramphus antiquus).

concentration, and liquid chromatography. By using the surrogate responses from the sample run and the relative response factor values, the concentrations of PFCA and PFSAs were recovery corrected.Method limit of detection was determined using in-house validation methods with an equivalent 3:1 signal-to-noise ratio. The limit of detection for all examined PFAS was $0.1 \mathrm{ng} / \mathrm{g}$, with the exception of perfluorodecane sulfonic acid (PFDS), which was $0.2 \mathrm{ng} / \mathrm{g}$. To check for contamination of analytes from solvents or the extraction process, 1 blank sample was prepared and analyzed with every batch of egg pools $(n=10)$. An in-house reference material of double-crested cormorant egg homogenate (based on eggs collected in 2003) was analyzed to assess reproducibility of the method. Recovery efficiencies of the PFAS internal standards were generally greater than $60 \%$.

\section{Stable isotope analysis}

Stable isotopes of delta 13 carbon $\left(\delta^{13} \mathrm{C}\right)$ and delta 15 nitrogen $\left(\delta^{15} \mathrm{~N}\right)$ were analyzed from the same egg homogenates as the chemical analyses. Detailed methods have been reported previously [36,51]. Subsamples of egg homogenate were prepared and sent to the Stable Isotope Facility, University of California, Davis, for analysis. All $\delta^{13} \mathrm{C}$ values were lipid normalized, because differences in lipid content can obscure

Table 1. Seabird species and years sampled at each site on the Pacific coast of Canada ${ }^{a}$

\begin{tabular}{|c|c|c|c|}
\hline Species & Site & Coordinates & Years Sampled \\
\hline Rhinoceros auklet & $\begin{array}{l}\text { North coast, } \\
\text { Lucy Island }\end{array}$ & $54^{\circ} 18^{\prime} \mathrm{N}, 130^{\circ} 37^{\prime} \mathrm{W}$ & 1990, 1995, 1999, 2003, 2006, 2010 \\
\hline Leach's storm petrel & $\begin{array}{l}\text { South coast, } \\
\text { Cleland Island }\end{array}$ & $49^{\circ} 10^{\prime} \mathrm{N}, 126^{\circ} 5^{\prime} \mathrm{W}$ & 1990, 1994, 1998, 2002, 2006, 2011 \\
\hline Double-crested cormorant & $\begin{array}{l}\text { South coast, } \\
\text { Mandarte Island }\end{array}$ & $43^{\circ} 38^{\prime} \mathrm{N}, 123^{\circ} 17^{\prime} \mathrm{W}$ & $\begin{array}{c}\text { 1973, } 1985 \text { (PFSAs only), } 1990 \\
\text { (PFSAs only), 1994, 1998, 2002, 2006, } 2011\end{array}$ \\
\hline Great blue heron & $\begin{array}{l}\text { South coast, } \\
\text { Fraser River }\end{array}$ & $\begin{array}{l}49^{\circ} 30^{\prime} \mathrm{N}, 123^{\circ} 14^{\prime} \mathrm{W} \\
49^{\circ} 26^{\prime} \mathrm{N}, 123^{\circ} 25^{\prime} \mathrm{W}\end{array}$ & $\begin{array}{l}1982 \text { (PFSAs only), } 1987 \text { (PFSAs only), } \\
\text { 1992, 1996, 2000, 2003, 2004, 2008, } 2012\end{array}$ \\
\hline
\end{tabular}

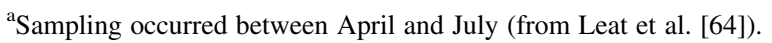

PFSAs = perfluoroalkyl sulfonates. 
variation in $\delta^{13} \mathrm{C}$ [36]. However, the Suess effect on $\delta^{13} \mathrm{C}$ [54] was not corrected for in the present study, given the relatively short time span of the data set presented ( $\sim 20-30 \mathrm{yr})$ compared with the timing of the Suess effect.

\section{Statistical analysis}

Where relevant, concentrations are given on a nanogram per gram wet weight basis, unless otherwise specified. Compounds that were below the limit of detection were divided by 2 to give a conservative estimate of concentration. Arithmetic means were calculated for each year in which multiple pooled samples were available for species and site. Where applicable, ¿PFSAs include perfluorobutane sulfonic acid (PFBS), perfluorohexane sulfonic acid (PFHxS), PFOS, and PFDS, whereas $\Sigma$ PFCAs include perfluorohexanoic acid (PFHxA), perfluoroheptanoic acid (PFHpA), PFOA, perfluorononanoic acid (PFNA), perfluorodecanoic acid (PFDA), perfluoroundecanoic acid (PFUdA), perfluorododecanoic acid (PFDoA), perfluorotridecanoic acid (PFTrDA), and perfluorotetradeconoic acid (PFTeDA). Any temporal analysis excludes murrelets, because only data from 2009 were available for this species.

All dominant compounds were log transformed before running either simple linear regression or quadratic regression to examine temporal changes. Doubling and halving times of log-transformed dominant compounds for each species before 2000 and after 2000 were conducted using the slope of a simple regression line and assuming first-order (exponential) increases where appropriate. This year was chosen because $3 \mathrm{M}$ phased out PFOS, PFOA, and related compounds from 2000 to 2002 [26]. In all cases $n=3$, except before 2000 for cormorants, where $n=5$; hence, results should be interpreted with caution.

A principal component analysis was used to examine the pattern of distribution of log transformed dominant compounds and other quantifiable compounds over the entire time period between all 4 species ( $n=6$ for each species and site combination for auklets, petrels, and cormorants; $n=7$ for herons). General linear models were used to examine the relationship between $(\log )$ LPFSA concentrations and $(\log )$ LPFCA concentrations, with species (auklet, petrel, cormorant, and heron), site (offshore and coastal), and lipid percentage as independent variables, and included both linear and quadratic terms for year to account for nonlinearity in the relationship with year. Because species and site had a significant effect on both (log) 2 PFSA and (log) $\Sigma$ PFCA concentrations over time, data were further divided into offshore (auklet and petrel) and coastal (cormorant and heron) species and reexamined. General linear models were run for $(\log ) \Sigma P F S A$ and $(\log ) \Sigma$ PFCA concentrations in auklets and petrels using lipid percentage, site, species, year, and year $^{2}$, and repeated for cormorants and herons.

Simple linear regression was used to examine temporal trends of stable isotopes of $\delta^{13} \mathrm{C}$ and $\delta^{15} \mathrm{~N}$. One outlier (petrel, Hippa Island, $\delta^{15} \mathrm{~N}, 0.32 \% ; \delta^{13} \mathrm{C},-29.57 \%$ ) was removed from the data set. Multiple linear regression was used to examine whether any relationships existed between $\delta^{13} \mathrm{C}, \delta^{15} \mathrm{~N}$, and lipid percentage to $\log$ natural transformed $\Sigma$ PFSA and $\mathrm{P}$ PFCA concentrations from all species collectively, and by species and site over time. Statistical analyses were conducted in Excel 2010 and R Ver 3.0.3. Significance level for all tests performed was set to $p<0.05$.

\section{RESULTS AND DISCUSSION}

\section{Dominant compounds}

The dominant PFSA compound for all species examined was PFOS $\left(C_{8}\right)$. In murrelet eggs sampled in 2009 , PFOS constituted more than $95 \%$ of $\Sigma$ PFSAs; in every sampling year, $\Sigma$ PFSAs constituted more than $97 \%$ in petrel eggs, more than $89 \%$ in auklet eggs, and more than $78 \%$ in cormorant eggs; and in heron eggs, PFOS constituted more than $60 \%$ of $\Sigma$ PFSAs in every sampling year (Supplemental Data, Table S2). Perfluorooctane sulfonic acid is typically the most commonly detected PFSA in wildlife $[5,10,30]$ regardless of species, tissue, or geographical location [20-23,55]. Concentrations observed are within the range of concentrations seen in other seabird species from, for example, Nunavut (Canada; 6.5-37 ng/g wet wt) [30], the Laurentian Great Lakes (83-933 ng/g wet wt) [31], and the North Sea (Germany; 20-170 ng/g wet wt) [56], but considerably lower than the maximum concentration observed from murre (Uria aalge) eggs in the Baltic Sea $(25-1324 \mathrm{ng} / \mathrm{g}$ wet wt) [32]. Perfluorodecane sulfonic acid $\left(\mathrm{C}_{10}\right)$ also showed quantifiable levels in all years for auklet eggs at both sites, although concentrations were far below that of PFOS, whereas PFDS was below $0.5 \mathrm{ng} / \mathrm{g}$ wet weight in murrelet eggs and remained below the limit of detection in petrel eggs except in 2011 at the south coast site. In the 2 coastal species, PFDS showed a reasonable contribution to $\Sigma$ PFSAs, in particular in herons, in which it contributed up to $37 \%$ to $\Sigma$ PFSAs in some years (Supplemental Data, Table S2). Similarly, PFDS was detected at low concentrations in herring gull (Larus argentatus) eggs collected from colonies throughout the Laurentian Great Lakes [31].

The dominant PFCA compounds for all 3 offshore species at all sites were 2 long-chained odd-numbered PFCAs, PFUdA $\left(\mathrm{C}_{11}\right)$, and PFTrDA $\left(\mathrm{C}_{13}\right)$. This pattern of long-chained oddnumbered PFCAs being detected at higher concentrations compared with even-numbered long-chained PFCAs has been reported in various species, such as beluga whales (Delphinapterus leucas) from Alaska [23], various Canadian Arctic biota (e.g., polar bears, Ursus maritimus; mink, Neovison vison; arctic fox, Vulpes lagopus; ringed seals, Phoca hispida; common loons, Gavia immer, and so forth) [57], herring gull eggs from Norway [58], and seabird species from the Canadian Arctic [30]. Dominant PFCA compounds in coastal species differed somewhat from the offshore species. In cormorants, PFOA $\left(\mathrm{C}_{8}\right)$ and PFNA $\left(\mathrm{C}_{9}\right)$ were the major contaminants. In herons, PFNA was initially dominant $(1992,1996)$, followed by PFTrDA; however, PFTrDA surpassed PFNA in all subsequent years, as did PFDoA $\left(\mathrm{C}_{12}\right)$ and PFUdA (Supplemental Data, Table S2). Other PFCA compounds found in quantifiable concentrations in the offshore species were PFNA, PFDA, PFDoA, and PFTeDA, and in coastal species PFHxA and PFHpA. All other compounds were either not found or were below the limit of detection.

\section{Temporal trends}

Perfluorooctane sulfonic acid contributed the most to total concentrations of PFAS in both offshore and coastal species regardless of location, although the total contribution was decreasing over time, whereas in the offshore auklets and petrels, total contribution of PFTrDA and PFUdA in particular increased with time. Perfluorooctane sulfonic acid concentrations increased in auklet eggs at both sites (Figure 2A, 2B) and in cormorant eggs (Figure 2E) until the early 2000s, when concentrations decreased. The PFOS contribution to total PFAS generally has decreased since the late 1990s (cormorants) and early 2000s (auklets; Table 2), in line with industry phaseouts [26]. Halving times for PFOS in auklet eggs after 2000 were -12.7 years and -21 years (south and north coast, respectively), whereas doubling time was 96.3 years for 

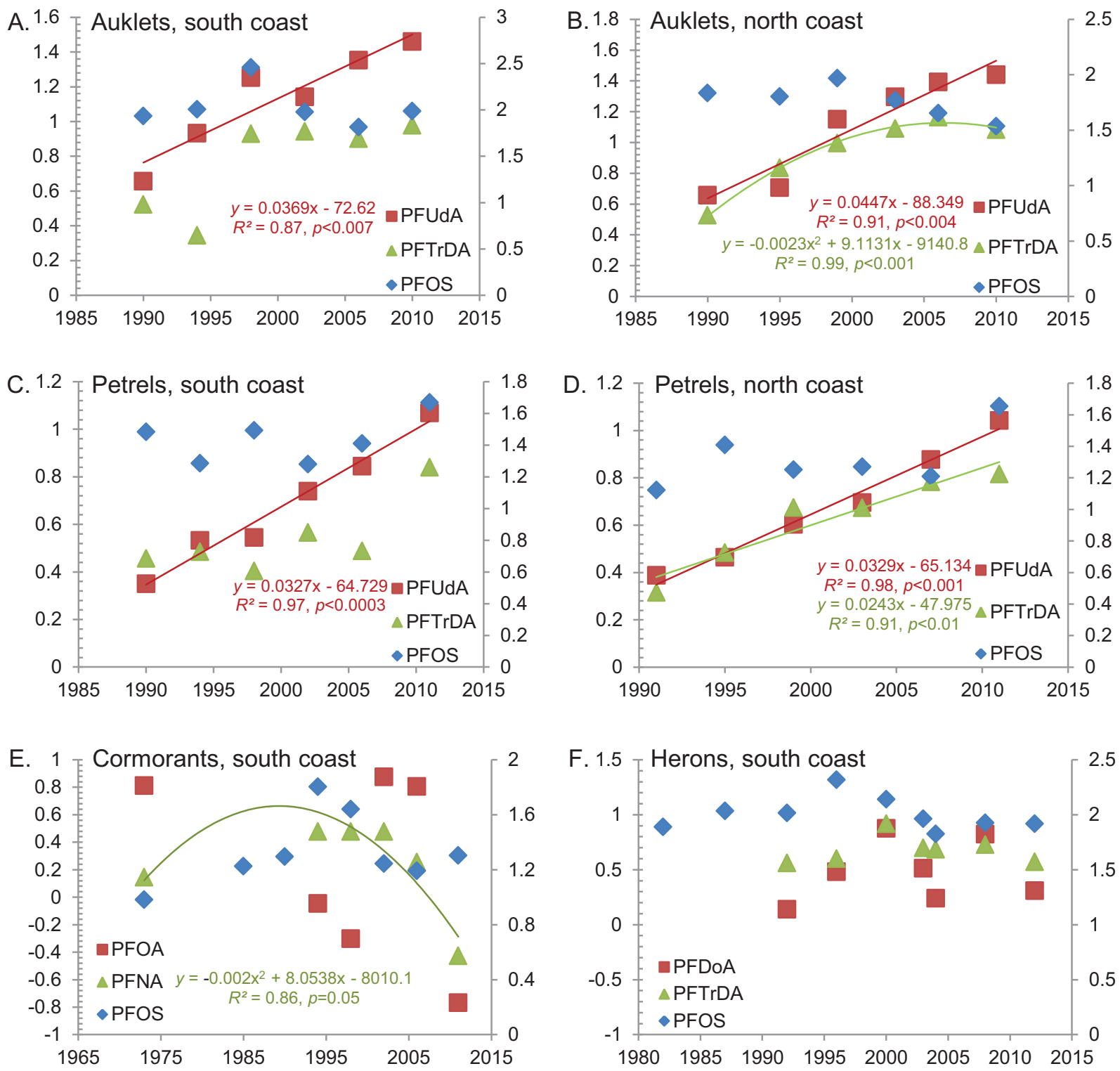

Figure 2. $\log (10)$ transformed perfluoroundecanoic acid (PFUdA) and perfluorotridecanoic acid (PFTrDA; primary y axis) and perfluorooctane sulfonic acid (PFOS; secondary $y$ axis), over time for $(\mathbf{A})$ rhinoceros auklets from the south coast; (B) rhinoceros auklets from the north coast; (C) Leach's storm-petrels from the south coast; and (D) Leach's storm-petrels from the north coast; (E) $\log (10)$ transformed perfluorooctanoic acid (PFOA) and perfluorononanoic acid (PFNA; primary $y$ axis) and PFOS (secondary $y$ axis) for double-crested cormorants from the south coast; and (F) $\log (10)$ transformed PFTrDA and perfluorododecanoic acid (PFDoA; primary $y$ axis) and PFOS (secondary $y$ axis) for great blue herons from the Fraser Estuary. Regression line and equation are only shown where a significant temporal change was observed.

cormorant eggs (Table 2). Comparably, an increasing trend for PFOS was observed in murre eggs from the Baltic Sea between 1968 (25 ng/g wet wt) and 2005 (614 ng/g wet wt) [32]; however, more recently (2001-2011) a decreasing trend has been indicated in this data set [59]. Perfluorooctane sulfonic acid concentrations in peregrine falcon (Falco peregrinus) eggs sampled from Sweden between 1974 and 2007 increased rapidly during the 1970s and early 1980s before leveling off [14].

By contrast, PFOS concentrations increased over the entire period in petrel eggs at both sites (Figure 2C, 2D), whereas in heron eggs PFOS concentrations showed little change over time (Figure 2F). The PFOS doubling times after 2000 in petrels were 15.9 years and 14.4 years (south and north coast, respectively), considerably shorter compared with times before 2000 of 693 years and 43 years, respectively (Table 2), indicating that concentrations of these compounds continue to increase in the oceanic environment and that phase-outs have not had a noticeable effect on contamination of petrels at those locations. By contrast, PFOS doubling time before 2000 in herons was 40.1 years and 385.1 years after 2000, indicating slowing accumulation in this species. Alternatively, because petrels spend the nonbreeding season in offshore pelagic environments, potentially closer to Asia, they may be less susceptible to regulatory actions in North America and may be affected by ongoing use in Asia. Conversely, PFOS in murre (U. lomvia) and fulmar (Fulmarus glacialis) eggs sampled from Prince Leopold Island in the Canadian Arctic between 1975 and 2011 did not change significantly over this period [30], also indicative of minimal effects wrought by phase-outs and other more recent North American and European regulations.

Despite regulations and restrictions on production and use in Europe [29] and North America [27,28], China began largescale production of PFOS in 2003 and has continued to produce PFOS for use in various industries [60-62]. Most PFAS 
Table 2. Doubling and halving times (in yr) for pre- and post-2000 values from simple linear regression for log transformed dominant compounds in rhinoceros auklet, Leach's storm petrel, double-crested cormorant, and great blue heron eggs ${ }^{\mathrm{a}}$

\begin{tabular}{|c|c|c|c|c|}
\hline \multirow[b]{2}{*}{ Compound } & \multicolumn{2}{|c|}{ Rhinoceros auklets, south coast } & \multicolumn{2}{|c|}{ Rhinoceros auklets, north coast } \\
\hline & Before $2000, n=3$ & After $2000, n=3$ & Before $2000, n=3$ & After $2000, n=3$ \\
\hline PFUdA & 9.3 & 18.8 & 13.1 & 34.5 \\
\hline PFTrDA & 13.6 & 39.6 & 13.3 & (301.4) \\
\hline Compound & Before $2000, n=3$ & After $2000, n=3$ & Before $2000, n=3$ & After $2000, n=3$ \\
\hline PFOS & 693.2 & 15.9 & 42.8 & 14.4 \\
\hline PFUdA & 28.5 & 18.7 & 25.9 & 16.0 \\
\hline \multirow[t]{2}{*}{ PFTrDA } & $(106.6)$ & 21.7 & 15.5 & 39.2 \\
\hline & \multicolumn{2}{|c|}{ Double-crested cormorant, south coast } & \multicolumn{2}{|c|}{ Great blue herons, south coast } \\
\hline PFOS & 22.7 & 96.3 & 40.1 & 385.1 \\
\hline PFDS & 0.0 & $(26.3)$ & Quadratic & $(10.4)$ \\
\hline PFOA & (16.0) & $(3.7)$ & 3.5 & Quadratic \\
\hline PFNA & 49.2 & (6.8) & (43.3) & 7.5 \\
\hline PFUdA & 11.2 & 4.5 & 22.8 & 6.3 \\
\hline PFTrDA & 9.8 & 15.8 & 16.5 & (59.8) \\
\hline
\end{tabular}

${ }^{a}$ Halving times are shown in parentheses for regressions that showed declining trends.

PFSA = perfluoroalkyl sulfonate; PFCA = perfluoroalkyl carboxylate; PFOA = perfluorooctanoic acid; PFNA = perfluorononanoic acid; PFUdA = perfluoroundecanoic acid; PFTrDA = perfluorotridecanoic acid; PFOS = perfluorooctane sulfonic acid; PFDS = perfluorodecane sulfonic acid.

producers are located in coastal China [63]. Increased production in China may have offset any progress in reducing PFOS gained by other industry phase-outs with respect to exposure of some Arctic biota [30]. Although little is known about their nonbreeding ground movements, petrels may spend some portion of the nonbreeding season in the western Pacific, likely in tropical waters [45]. Overwintering exposure has been shown to have a significant effect on polybrominated diphenyl ether (PBDE) concentrations in great skua (Stercorarius skua) [64]. The elimination half-life of PFOS is rather variable, ranging from an estimated 13.6 days in mallard (Anas platyrhynchos) serum and 20.1 days in northern bobwhite quail (Colinus virginianus) serum [65] to 125 days in male chicken serum (Gallus gallus) [66], more than $89 \mathrm{~d}$ in male rat serum [65], and 100 days to 200 days in cynomolgus monkey (Macaca fascicularis) serum [67], to 8.6 years in humans [68]. Thus, the continued increasing PFOS trends observed in petrels may be attributable to carryover from winter exposure. Furthermore, if breeding-ground exposure was solely accountable for the observed concentrations, expecting similar temporal trends in auklet and petrel eggs from the south coast, closer to industrial regions in southern Canada and the United States, would be reasonable.

For both offshore species at all sites, PPFCAs showed increasing temporal trends. Perfluoroundecanoic acid showed consistent, and mostly significant, increasing temporal trends in both species at all sites (Figure 2A-D). Perfluorotridecanoic acid showed significant increasing trends in auklet eggs at Cleland Island (Figure 2A), petrel eggs at Hippa Island (Figure 2D), and general increasing trends in petrel eggs from Cleland Island (Figure 2C). However, in auklet eggs from Lucy Island, an increase in PFTrDA concentration was followed by a significant decrease (Figure 2B). Significant increases $(p<0.01)$ were found in 2PFCA for both auklets and petrels at all sites (not shown). By contrast, $\Sigma$ PFCAs in the coastal species showed some decrease in concentration in the most recent years (not shown). This pattern was also observed in the dominant PFCA compounds (Figure 2E, 2F), which is most likely a reflection of the proximity to urban sources.

Similar to our findings, PFUdA and PFTrDA were found to significantly increase in eggs of thick-billed murres and northern fulmars from Prince Leopold Island, Canadian Arctic, between 1975 and 2011 [30]. At 3 sites in the North and Baltic Sea, longer-chained PFCAs increased over the last $20 \mathrm{yr}$ in herring gull eggs [56]. The $\Sigma$ PFCA concentrations increased significantly in the eggs of 4 of 7 herring gull colonies sampled from the Laurentian Great Lakes in 1990 and 1997 to 2010 [31]; in herring gull eggs from 2 colonies in northern Norway from 1983 to 1993 , and then showed either a weak increase after 1993 or a leveling off [58]. Both PFUdA and PFTrDA are unintentionally produced substances [69]. Instead, their presence in the environment is probably attributable to both direct (impurities in PFOA and PFNA production) and indirect sources (atmospheric transport and degradation of precursors such as the ammonium salt of PFNA [69]).

Although an agreement was made in the United States in the mid-2000s between the USEPA and 8 major global companies to decrease emissions and product content of PFOA, higher homologues, and precursors by $95 \%$ by 2010 [27,69], and in Canada an agreement was made in 2010 between Environment Canada, Health Canada, and 4 companies from the perfluorinated product industry to restrict PFCAs in products [28], clearly not enough time has elapsed to observe a related effect on $\Sigma$ PFCA concentrations in petrel and auklet eggs. However, a general decrease in recent sampling years was seen in the coastal species. Further 
monitoring is warranted to track PFCA development in light of North American agreements.

\section{Species differences}

Differences are apparent, especially between the coastal and offshore species. In the most recent year of sampling, PFOS concentration in herons from a colony located within the city of Vancouver that feed in the Fraser River estuary were the greatest among the sampled species. Surprisingly, PFOS concentration was second lowest in cormorants, only being lower in ancient murrelets, despite the relative proximity of the cormorant colony to urbanized areas in the Salish Sea (Table 1, Figure 3A). Concentrations of PFUdA and PFTrDA in the 2 coastal species were considerably lower compared with the offshore species (Figure 3B), indicating a difference in exposure sources between coastal and offshore; for example, coastal species are exposed because of their relative proximity to major cities, and where regulations on PFAS appear to be having a positive effect. It appears that the more offshore species may be exposed during nonbreeding ground exposure or via redistribution of these compounds to the pelagic environment from urban sources.

Little variation was seen in spatial pattern of the 3 dominant compounds between the offshore species. Those results support the idea that PFAS levels in eggs of the offshore species primarily reflect exposure during the 7 months/year to 8 months/ year both species spend on nonbreeding grounds rather than the 4 to 5 months/year that they spend at the breeding grounds [44], especially because nutrients in the eggs are deposited at the start of the breeding season, before they have several months' recent exposure. We suggest either that egg nutrients (including PFAS) are deposited at varying times after arriving from the nonbreeding grounds or that they are derived from tissues that have a longer PFAS half-life than the 14 to 20 days reported for some avian species [65] and may be similar to that seen in chicken serum [66]. However, clear differences are seen among the species; herons had the highest PFOS concentration, cormorants had the lowest concentrations of both dominant PFCAs, and the offshore species had the highest concentrations of dominant PFCAs. Those observations are supported by general linear model results examined for the entire time series for each species (ancient murrelet excluded), where species and site had a significant effect on log transformed $\Sigma$ PFSA and $\Sigma$ PFCA concentrations when all 4 species were combined $(p<0.0001, p<0.0001$ for site and species for both $[\log ]$ $\Sigma$ PFSA and [log] $\Sigma$ PFCA, respectively), as did lipid percentage on $[\log ] \Sigma$ PFSA $(p<0.04)$ but not $(\log ) \Sigma$ PFCA. Species differences could be attributable to differing exposure, proximity to urban centers and sources, and dietary and possibly metabolism differences.

More than $70 \%$ of the variance was explained by the first 2 axes of a principal component analysis examining the pattern of distribution of log-transformed dominant PFAS compounds and other quantifiable compounds among the 4 species (murrelets excluded) over the whole sampling period (Figure 4). Minimal overlap was seen between auklets, herons, and cormorants, and no overlap was seen with petrels. Petrels appear to be uninfluenced by any particular compound or group of compounds over time. In contrast, the coastal species appear to be more influenced by PFSA compounds, and auklets are more influenced by PFCA compounds, again indicating species differences in PFAS exposure. No clear shift in compound influence was seen before 2000 or after 2000 for any species.

\section{Stable isotope analysis}

Neither $\mathrm{C}$ nor $\mathrm{N}$ stable isotope ratios varied much over time from auklet or petrel eggs at any site, and murrelet egg stable isotope values were reasonably stable among individuals for the single year sampled. For cormorants, $\delta^{15} \mathrm{~N}$ varied little over time, whereas $\delta^{13} \mathrm{C}$ showed a nonsignificant increase. Based on earlier dietary assessments, auklets and petrels are offshore pelagic feeders [70], as indicated by $\delta^{13} \mathrm{C}$ values, with petrels being the more pelagic of the 2 , as expected. Cormorant egg $\delta^{13} \mathrm{C}$ values ( $-13.2 \%$ to $-17.6 \%$ ) are more enriched compared with auklet $(-17.3 \%$ to $-19.4 \%$ ), murrelet $(-18.5 \%$ o to $-19.7 \%$ o), and petrel eggs $(-20.7 \%$ o to $-23.7 \%$ ) indicating that auklets, murrelets, and petrels feed more offshore compared with cormorants, with petrels feeding the farthest from shore. Assuming that a fractionation factor of $3.2 \%$ to $3.4 \%$ o represents an average for multiple trophic transfers [34], neither auklet nor petrels transcended more than 1 trophic level over the examined period. However, cormorant $\delta^{15} \mathrm{~N}$ values spanned a range of $3.7 \%$, and $\delta^{13} \mathrm{C}$ values spanned a range of $4.4 \%$, indicative more of temporal dietary variation rather than a change in trophic feeding level given the nonsignificant changes seen over time for both of these stable isotopes. Values for $\delta^{15} \mathrm{~N}$ were between $11 \%$ and $16 \%$ or for auklets, murrelets, and petrels, and $13 \%$ and $17.5 \%$ or cormorants. When temporal
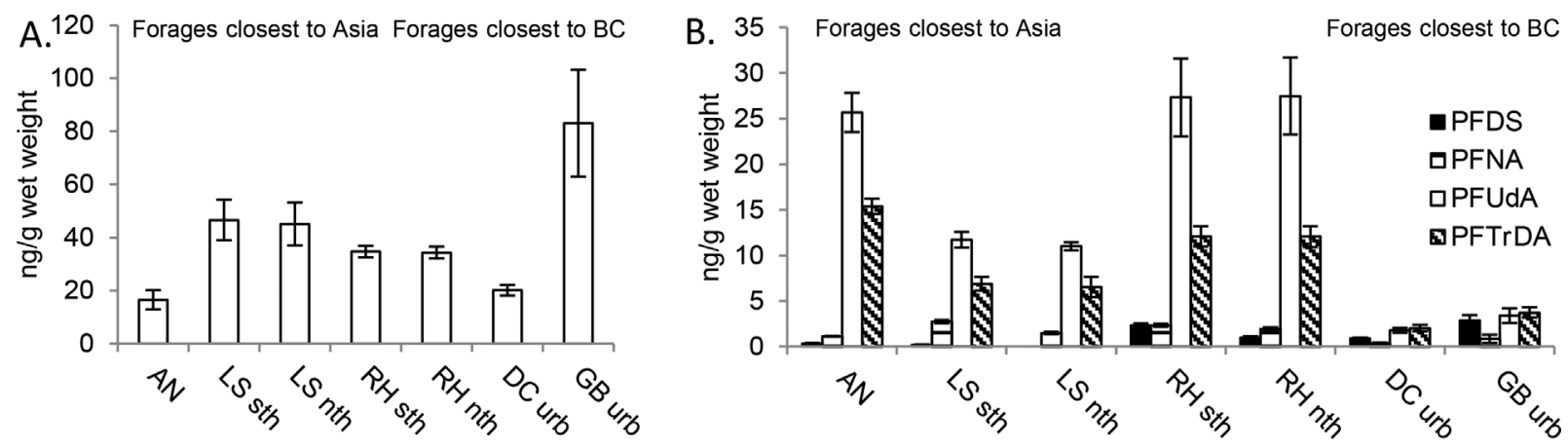

Figure 3. (A) Average perfluorooctane sulfonic acid (PFOS) concentration (ng/g wet wt \pm standard error of the mean [SEM]) and (B) average perfluorodecane sulfonic acid (PFDS), perfluorononanoic acid (PFNA), perfluoroundecanoic acid (PFUdA), and perfluorotridecanoic acid (PFTrDA) concentrations (ng/g wet $\mathrm{wt} \pm \mathrm{SEM})$ in ancient murrelet, rhinoceros auklet, Leach's storm-petrel, double-crested cormorant, and great blue heron eggs for the most recent sampling year. AN = ancient murrelet, Langara Island (north coast; 2009); RH sth = rhinoceros auklets, Cleland Island (south coast; 2010); RH nth = rhinoceros auklets, Lucy Island (north coast; 2010); LS sth = Leach's storm-petrels, Cleland Island (south coast; 2011); LS nth = Leach's storm-petrels, Hippa Island (north coast; 2011); DC $u r b=$ double-crested cormorants (south coast, urban; 2011); GB urb = great blue herons (south coast, urban; 2012). 


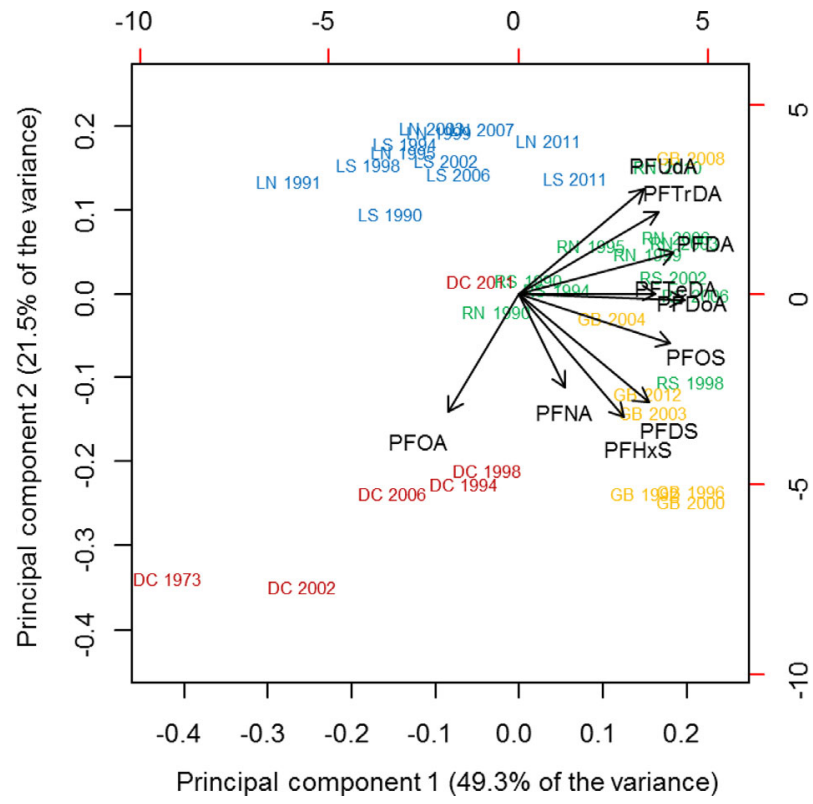

Figure 4. Principal component analysis of all compounds that showed quantifiable concentrations for rhinoceros auklets at the south coast (RS; green), rhinoceros auklets at the north coast (RN; green), Leach's stormpetrels at the south coast (LS; blue), Leach's storm-petrels at the north coast (LN; blue), double-crested cormorants (DC; red), and great blue herons (GB; yellow) for the whole monitoring period. Years are shown next to each species and site; for example, DC 2002 indicates double-crested cormorants, 2002.

stable isotope data for auklet, petrel, and cormorants were combined, no significant relationships were observed between $\delta^{13} \mathrm{C}, \delta^{15} \mathrm{~N}$, or lipid percentage and $(\log ) \Sigma$ PFSA, and $\delta^{13} \mathrm{C}$ and $(\log ) \Sigma$ PFCA. The lack of relationships and variation in $\delta^{13} \mathrm{C}$ and $\delta{ }^{15} \mathrm{~N}$ over time indicates that diet has not changed in any marked way for these bird species. Therefore, diet alone is unlikely to be driving the variation in observed concentrations in PFAS in these species.

\section{Toxicological implications}

Various effects have been observed from laboratory experiments examining PFOS exposure in birds, ranging from decreased pipping ability from doses as low as $0.1 \mu \mathrm{g}$ PFOS/g egg weight [71-73], to pathological changes in the liver, brain asymmetry, and increases in spleen mass and plasma lysozyme activity indicative of innate immune function from doses of $1 \mu \mathrm{g} / \mathrm{g}$ to $5 \mu \mathrm{g} / \mathrm{g}$ egg weight [73,74], to reductions in body weight [75]. O'Brien et al. [71] examined PFUdA and PFDS in chicken eggs but found no effect on pipping success at concentrations up to $10 \mu \mathrm{g} / \mathrm{g}$ egg weight. Estimated median lethal dose values range from $4.9 \mu \mathrm{g} / \mathrm{g}$ egg weight to $93 \mu \mathrm{g} / \mathrm{g}$ egg weight [72,73], although confidence intervals vary over several orders of magnitude. A toxic reference value of $1.7 \mu \mathrm{g} / \mathrm{g}$ egg has been reported for northern bobwhite quail and mallard duck eggs [75,76] (assuming $1 \mathrm{~mL}$ egg corresponds to $1 \mathrm{~g}$ ). The lowest-observable-adverse-effect level (LOAEL) for PFOS has been estimated as $0.1 \mu \mathrm{g}$ PFOS/g egg weight [73]. Maximum PFOS concentrations observed in herons and auklets from the south coast colony of Cleland Island were above the LOAEL for PFOS, where potential effects on pipping success may be observed. However, the most recent year of sampling shows PFOS concentrations in all 4 species to be below the LOAEL. Further monitoring and enforcement of agreements and regulations implemented are necessary, and more research on toxicological effects of exposure to PFCA compounds is needed. If concentrations of some of these PFAS compounds continue to increase, further toxicological data, other than single-species egg injection studies, on exposure to birds may be warranted.

\section{SUPPLEMENTAL DATA}

Tables S1-S2. (78 KB DOC).

Acknowledgment-The authors acknowledge Environment Canada as the primary funding source and contributions from NSERC (grant number 402344-2011), as well as the many people involved in egg collection, preparation, archiving, chemical analysis, and data management over the years.

Disclaimer-The authors have no conflict of interests.

Data availability-Yearly averages for contaminants examined are available in the present study as supplemental data. Further details can be requested from the authors (John.Elliott@ec.gc.ca).

\section{REFERENCES}

1. Sinclair E,Kim SK, Akinleye HB, Kannan K. 2007. Quantitation of gasphase perfluoroalkyl surfactants and fluorotelomer alcohols released from nonstick cookware and microwave popcorn bags. Environ Sci Technol 41:1180-1185.

2. Key B, Howell R, Criddle C. 1998. Defluorination of organofluorine sulfur compounds by Psuedomonas sp. strain D2. Environ Sci Technol 32:2283-2287.

3. Moody C, Field J. 2000. Perfluorinated surfactants and the environmental implications of their use in fire-fighting foams. Environ Sci Technol 34:3864-3870.

4. Prevedouros K, Cousins I, Buck RC, Korzeniowski SH. 2006. Sources, fate and transport of perfluorocarboxylates. Environ Sci Technol 40: 32-44.

5. Conder JM, Hoke RA, De Wolf W, Russell MH, Buck RC. 2008. Are PFCAs bioaccumulative? A critical review and comparison with regulatory criteria and persistent lipophilic compounds. Environ Sci Technol 42:995-1003.

6. Ahrens L. 2011. Polyfluoroalkyl compounds in the aquatic environment: A review of their occurrence and fate. J Environ Monit 13:20-31.

7. Key B, Howell R, Criddle C. 1999. Fluorinated organics in the biosphere. Environ Sci Technol 31:2445-2454.

8. Mariussen E. 2012. Neurotoxic effects of perfluoroalkylated compounds: Mechanisms of action and environmental relevance. Arch Toxicol 86:1349-1367.

9. Ahrens L, Xie Z, Ebinghaus R. 2010. Distribution of perfluoroalkyl compounds in seawater from northern Europe, Atlantic Ocean, and Southern Ocean. Chemosphere 78:1011-1016.

10. Houde M, Martin J, Letcher RJ, Solomon KR, Muir D. 2006. Biological monitoring of polyfluoroalkyl substances: A review. Environ Sci Technol 40:3463-3473.

11. Barber JL, Berger U, Chaemfa C, Huber S, Jahnke A, Temme C, Jones KC. 2007. Analysis of per- and polyfluorinated alkyl substances in air samples from Northwest Europe. J Environ Monit 9:530-541.

12. Filipovic M, Berger U, McLachlan MS. 2013. Mass balance of perfluoroalkyl acids in the Baltic sea. Environ Sci Technol 47:40884095.

13. Gebbink WA, Letcher RJ. 2012. Comparative tissue and body compartment accumulation and maternal transfer to eggs of perfluoroalkyl sulfonates and carboxylates in Great Lakes herring gulls. Environ Pollut 162:40-47.

14. Holmström KE, Johansson A-K, Bignert A, Lindberg P, Berger U. 2010. Temporal trends of perfluorinated surfactants in Swedish peregrine falcon eggs (Falco peregrinus), 1974-2007. Environ Sci Technol 44:4083-4088.

15. Kannan K, Choi J-W, Iseki N, Senthilkumar K, Kim DH, Giesy JP. 2002. Concentrations of perfluorinated acids in livers of birds from Japan and Korea. Chemosphere 49:225-231.

16. Nordén M, Berger U, Engwall M. 2013. High levels of perfluoroalkyl acids in eggs and embryo livers of great cormorant (Phalacrocorax carbo sinensis) and herring gull (Larus argentatus) from Lake Vänern, Sweden. Environ Sci Pollut Res Int 20:8021-8030. 
17. Kannan K, Tao L, Sinclair E, Pastva SD, Jude DJ, Giesy JP. 2005. Perfluorinated compounds in aquatic organisms at various trophic levels in a Great Lakes food chain. Arch Environ Contam Toxicol 48:559-566.

18. Martin JW, Whittle DM, Muir DCG, Mabury SA. 2004. Perfluoroalkyl contaminants in a food web from Lake Ontario. Environ Sci Technol 38:5379-5385.

19. Taniyasu S, Kannan K, Horii Y, Hanari N, Yamashita N. 2003. A survey of perfluorooctane sulfonate and related perfluorinated organic compounds in water, fish, birds, and humans from Japan. Environ Sci Technol 37:2634-2639.

20. Ahrens L, Siebert U, Ebinghaus R. 2009. Total body burden and tissue distribution of polyfluorinated compounds in harbor seals (Phoca vitulina) from the German Bight. Mar Pollut Bull 58:520-525.

21. Fair PA, Houde M, Hulsey TC, Bossart GD, Adams J, Balthis L, Muir DCG. 2012. Assessment of perfluorinated compounds (PFCs) in plasma of bottlenose dolphins from two southeast US estuarine areas: Relationship with age, sex and geographic locations. Mar Pollut Bull 64:66-74.

22. Houde M, Bujas T, Small J, Wells R, Fair P, Bossart G, Solomon K, Muir D. 2006. Biomagnification of perfluoroalkyl compounds in the bottlenose dolphin (Tursiops truncatus) food web. Environ Sci Technol 40:4138-4144.

23. Reiner JL, O'Connell SG, Moors AJ, Kucklick JR, Becker PR, Keller JM. 2011. Spatial and temporal trends of perfluorinated compounds in beluga whales (Delphinapterus leucas) from Alaska. Environ Sci Technol 45:8129-8136.

24. Lindh CH, Rylander L, Toft G, Axmon A, Rignell-Hydbom A, Giwercman A, Pedersen HS, Góalczyk K, Ludwicki JK, Zvyezday V, Vermeulen R, Lenters V, Heederik D, Bonde JP, Jönsson BA. 2012. Blood serum concentrations of perfluorinated compounds in men from Greenlandic Inuit and European populations. Chemosphere 88:12691275

25. Elliott JE, Elliott KH. 2013. Tracking marine pollution. Science 340:556-558

26. US Environmental Protection Agency. 2000. EPA and 3M announce phaseout of PFOS. [cited 2014 August 14]. Available from: yosemite.epa. gov/opa/admpress.nsf/0/33AA946E6CB11F35852568E1005246B4

27. US Environmental Protection Agency. 2006. 2010/2015 PFOA Stewardship Program. [cited 2014 September 18]. Available from: http://www.epa.gov/opptintr/pfoa/pubs/stewardship/

28. Environmental Canada. 2010. Environmental Performance Agreement: Perfluorinated carboxylic acids (PFCAs) and their precursors (20102015). [cited 2014 September 18]. Available from: http://ec.gc.ca/epeepa/default.asp?lang =En\&n=0D8C879E-1\#X-2013092511492112

29. European Union. 2006. Directive 2006/122/EC. 2006. Directive 2006/ $122 /$ EC of the European Parliament and of the Council of 12 December 2006. Off J Eur Union L372/32-34.

30. Braune BM, Letcher RJ. 2013. Perfluorinated sulfonate and carboxylate compounds in eggs of seabirds breeding in the Canadian Arctic: Temporal trends (1975-2011) and interspecies comparison. Environ Sci Technol 47:616-624.

31. Gebbink WA, Letcher RJ, Hebert CE, Chip Weseloh DV. 2011. Twenty years of temporal change in perfluoroalkyl sulfonate and carboxylate contaminants in herring gull eggs from the Laurentian Great Lakes. J Environ Monit 13:3365-3372.

32. Holmström KE, Järnberg U, Bignert A. 2005. Temporal trends of PFOS and PFOA in guillemot eggs from the Baltic Sea, 1968-2003. Environ Sci Technol 39:80-84.

33. Tittlemier SA, Pepper K, Seymour C, Moisey J, Bronson R, Cao X-L, Dabeka RW. 2007. Dietary exposure of Canadians to perfluorinated carboxylates and perfluorooctane sulfonate via consumption of meat, fish, fast foods, and food items prepared in their packaging. $J$ Agric Food Chem 55:3203-3210.

34. Post DM. 2002. Using stable isotopes to estimate trophic position: Models, methods and assumptions. Ecology 83:703-718.

35. Braune BM, Donaldson GM, Hobson KA. 2002. Contaminant residues in seabird eggs from the Canadian Arctic. II. Spatial trends and evidence from stable isotopes for intercolony differences. Environ Pollut 117:133-145.

36. Elliott KH, Davis M, Elliott JE. 2014. Equations for lipid normalization of carbon stable isotope ratios in aquatic bird eggs. PLoS One 9:e83597.

37. Hebert CE, Weseloh DVC. 2006. Adjusting for temporal change in trophic position results in reduced rates of contaminant decline. Environ Sci Technol 40:5624-5628.

38. Sealy S. 1975. Feeding ecology of the ancient and marbled murrelets near Langara Island, British Columbia. Can J Zool 53:418-433.
39. Hedd A, Montevecchi WA. 2006. Diet and trophic position of Leach's storm-petrel Oceanodroma leucorhoa during breeding and moult, inferred from stable isotope analysis of feathers. Mar Ecol Prog Ser 322:291-301.

40. Burger AE, Wilson RP, Garnier D, Wilson M-P. 1993. Diving depths, diet, and underwater foraging of rhinoceros auklets in British Columbia. Can J Zool 71:2528-2540.

41. Ydenberg R. 1989. Growth-mortality trade-offs and the evolution of juvenile life histories in the Alcidae. Ecology 70:1494-1506.

42. Vermeer K. 1979. Nesting requirements, food and breeding distribution of rhinoceros auklets, Cerorhinca monocerata, and tufted puffins, Lunda cirrhata. Ardea 67:101-110.

43. Wilson U, Manuwal D. 1986. Breeding biology of the rhionceros auklet in Washington. Condor 88:143-155.

44. Wilbur H. 1969. The breeding biology of Leach's petrel, Oceanodroma leucorhoa. The Auk 86:433-442.

45. Huntington C, Butler R, Mauck R. 1996. Leach's Storm-Petrel (Oceanodroma leucorhoa), The Birds of North America Online. In Poole A, ed, Ithaca: Cornell Lab of Ornithology. [cited 2014 September 10]. Available from: http://bna.birds.cornell.edu/bna/species/233

46. Gaston A, Dechesne S. 1996. Rhinoceros Auklet (Cerorhinca monocerata), The Birds of North America Online. In Poole, A, ed. Ithaca: Cornell Lab of Ornithology. [cited 2014 September 10]. Available from http://bna.birds.cornell.edu/bna/species/212

47. Mercer DM, Haig SM, Roby DD. 2013. Phylogeography and population genetic structure of double-crested cormorants (Phalacrocorax auritus). Conserv Genet 14:823-836.

48. Custer T, Hines R, Melancon M, Hoffman D, Wickliffe J, Bickham J, Martin J, Henshel D. 1997. Contaminant concentrations and biomarker response in great blue heron eggs from 10 colonies on the upper Mississippi River, USA. Environ Toxicol Chem 16:260-271.

49. Elliott JE, Harris ML, Wilson LK, Whitehead PE, Norstrom RJ. 2001. Monitoring temporal and spatial trends in polychlorinated dibenzo-pdioxins (PCDDs) and dibenzofurans (PCDFs) in eggs of great blue heron (Ardea herodias) on the coast of British Columbia, 1983-1998. Ambio 30:416-428.

50. Harris M, Wilson L, Norstrom R, Elliott J. 2003. Egg concentrations of polychlorinated dibenzo-p-dioxins and dibenzofurans in double-crested (Phalacrocorax auritus) and pelagic ( $P$. pelagicus) cormorants from the Strait of Georgia, Canada, 1973-1998. Environ Sci Technol 37: 822-831.

51. Miller A, Elliott J, Elliott K, Guigueno M, Wilson L, Sandi L, Idriss A. 2014. Spatial and temporal trends in brominated flame retardants in seabirds from the Pacific Coast of Canada. Environ Pollut 195:48-55.

52. Miller A, Elliott J, Elliott K, Guigueno MF, Wilson L, Lee S, Idrissi A. 2015. Brominated flame retardant trends in aquatic birds from the Salish Sea region of the west coast of North America, including a mini-review of recent trends in marine and estuarine birds. Sci Total Environ 502:60-69.

53. Elliott J, Norstrom R, Kennedy S, Fox G. 1988. Progress in environmental specimen banking. In Wise S, Zeisler R, Goldstein G, eds, National Bureau of Standards Special Publication 740. US Government Printing Office, Washington, DC

54. Gruber N, Keeling D, Bacastow RB, Guenther PR, Lueker TJ, Wahlen M, Meijer HAJ, Mook WG, Stocker TF. 1999. Spatiotemporal patterns of carbon-13 in the global surface oceans and the oceanic Suess effect. Global Biogeochem Cycles 13:307-335.

55. Houde M, De Silva AO, Muir DCG, Letcher RJ. 2011. Monitoring of perfluorinated compounds in aquatic biota: An updated review. Environ Sci Technol 45:7962-7973.

56. Fliedner A, Rüdel H, Jürling H, Müller J, Neugebauer F, SchröterKermani C. 2012. Levels and trends of industrial chemicals (PCBs, PFCs, PBDEs) in archived herring gull eggs from German coastal regions. Environ Sci Eur 24:7.

57. Martin JW, Smithwick MM, Braune BM, Hoekstra PF, Muir DCG, Mabury SA. 2004. Identification of long-chain perfluorinated acids in biota from the Canadian Arctic. Environ Sci Technol 38:373-380.

58. Verreault J, Berger U, Gabrielsen GW. 2007. Trends of perfluorinated alkyl substances in herring gull eggs from two coastal colonies in northern Norway: 1983-2003. Environ Sci Technol 41:6671-6677.

59. Bignert A, Danielsson S, Faxneld S, Miller A, Nyberg E, Berger U, Borg H, Eriksson U, Holm K, Nylund K, Egebäck A-L, Haglund P. 2013. Comments Concerning the National Swedish Contaminant Monitoring Programme in Marine Biota, 2013. Swedish Museum of Natural History, Stockholm, Sweden, p 262.

60. Ministry of Environmental Protection of the People's Republic of China. 2008. Additional information on production and use of PFOS 
Memorandum to Mr. Donald Cooper, Secretariat of the Stockholm Convention, Châtelaine, Switzerland. Beijing, China.

61. Han W. 2009. PFOS related actions in China. Proceedings, International Workshop on Managing Perfluorinated Chemicals and Transitioning to Safer Alternatives, Geneva, Switzerland, February 12 13, 2009.

62. Lim TC, Wang B, Huang J, Deng S, Yu G. 2011. Emission inventory for PFOS in China: Review of past methodologies and suggestions. Sci World J 11:1963-1980.

63. Chen C, Lu Y, Zhang X, Geng J, Wang T, Shi Y, Hu W, Li J. 2009. A review of spatial and temporal assessment of PFOS and PFOA contamination in China. Chem Ecol 25:163-177.

64. Leat E, Bourgeon S, Magnusdottir E, Gabrielsen G, Grecian W, Hanssen S, Olafsdottir K, Petersen A, Phillips R, Strøm H, Ellis S, Fisk A, Bustnes J, Furness R, Borgå K. 2013. Influence of wintering area on persistent organic pollutants in a breeding migratory seabird. Mar Ecol Prog Ser 491:277-293.

65. Newsted JL, Coady KK, Beach SA, Butenhoff JL, Gallagher S, Giesy JP. 2007. Effects of perfluorooctane sulfonate on mallard and northern bobwhite quail exposed chronically via the diet. Environ Toxicol Pharmacol 23:1-9.

66. Yoo H, Guruge KS, Yamanaka N, Sato C, Mikami O, Miyazaki S, Yamashita N, Giesy JP. 2009. Depuration kinetics and tissue disposition of PFOA and PFOS in white leghorn chickens (Gallus gallus) administered by subcutaneous implantation. Ecotoxicol Environ Saf 72:26-36.

67. Seacat AM, Thomford PJ, Hansen KJ, Olsen GW, Case MT, Butenhoff JL. 2002. Subchronic toxicity studies on perfluorooctanesulfonate potassium salt in cynomolgus monkeys. Toxicol Sci 68:249-264.

68. Hekster FM, de Voogt P, Pijinenburg AMCM, Laane RWPM. 2002. Perfluoroalkylated substances: Aquatic environmental assessment. Report RIKZ/2002.043. University of Amsterdam and RIKZ (The State Institute for Coast and Sea), Amsterdam, The Netherlands.
69. Buck RC, Franklin J, Berger U, Conder JM, Cousins IT, de Voogt P, Jensen AA, Kannan K, Mabury SA, van Leeuwen SPJ. 2011. Perfluoroalkyl and polyfluoroalkyl substances in the environment: Terminology, classification, and origins. Integr Environ Assess Manag 7:513-541.

70. Hobson KA, Piatt JFJ, Pitocchelli J. 1994. Using stable isotopes to determine seabird trophic relationships. J Anim Ecol 63:786-798.

71. O'Brien JM, Crump D, Mundy LJ, Chu S, McLaren KK, Vongphachan V, Letcher RJ, Kennedy SW. 2009. Pipping success and liver mRNA expression in chicken embryos exposed in ovo to C8 and C11 perfluorinated carboxylic acids and $\mathrm{C} 10$ perfluorinated sulfonate. Toxicol Lett 190:134-139.

72. O'Brien JM, Carew AC, Chu S, Letcher RJ, Kennedy SW. 2009. Perfluorooctane sulfonate (PFOS) toxicity in domestic chicken (Gallus gallus domesticus) embryos in the absence of effects on peroxisome proliferator activated receptor alpha (PPARalpha)-regulated genes. Comp Biochem Physiol 149:524-530.

73. Molina ED, Balander R, Fitzgerald SD, Giesy JP, Kannan K, Mitchell R, Bursian SJ. 2006. Effects of air cell injection of perfluorooctane sulfonate before incubation on development of the white leghorn chicken (Gallus domesticus) embryo. Environ Toxicol Chem 25: 227-232.

74. Peden-Adams MM, Stuckey JE, Gaworecki KM, Berger-Ritchie J, Bryant K, Jodice PG, Scott TR, Ferrario JB, Guan B, Vigo C, Boone JS, McGuinn WD, DeWitt JC, Keil DE. 2009. Developmental toxicity in white leghorn chickens following in ovo exposure to perfluorooctane sulfonate (PFOS). Reprod Toxicol 27:307-318.

75. Newsted JL, Jones PD, Coady K, Giesy JP. 2005. Avian toxicity reference values for perfluorooctane sulfonate. Environ Sci Technol 39:9357-9362.

76. Holmström KE, Berger U. 2008. Tissue distribution of perfluorinated surfactants in common guillemot (Uria aalge) from the Baltic Sea. Environ Sci Technol 42:5879-5884. 